\title{
Analysis of India's Policy Reforms
}

\author{
Rajesh Chadha, Sanjib Pohit, Alan V. Deardorff and Robert M. Stern
}

\section{INTRODUCTION}

$\mathbb{T}$ HE process of major economic reforms undertaken in the Indian economy has now completed six years of implementation. The economy has entered into a new phase of development directed towards becoming globally competitive through opening up to trade, foreign investment, and technology inflows. The unilateral reforms of the trade and domestic policies of India, along with reforms of the tax regime since 1991, represent a significant departure from the policy framework of the previous four decades and are important to the future course of the Indian economy. There is an ongoing debate in India regarding the likely impacts of sectoral reforms on output, employment and other variables that affect the economic wellbeing of the country's population. It thus becomes important to evaluate the effects of such policy reforms on factor prices, output, and trade, along with inter-sectoral movement of resources, viz. land, labour, and capital. To address these issues, we use a 34-sector computable general equilibrium (CGE) model for India. Though such ex-ante analysis may not be replicated ex-post due to various macroeconomic and other factors that our model does not capture, the positive results nevertheless go a long way in establishing the credibility of the reforms process. We hope therefore that our analysis will provide a more solid underpinning for the ongoing policy debate.

The paper proceeds as follows. The policy relevance of our research is outlined in Section 2. In Section 3, we elaborate briefly the essential features of the India CGE model. The various policy scenarios are discussed in Section 4, and the results are presented in Section 5. In Section 6, we report on the sensitivity of the model to changes in some of its essential parameters. Our findings are summarised in Section 7.

RAJESH CHADHA is Reader in the Department of Economics, Hindu College, University of Delhi and a Senior Consultant to the National Council of Applied Economic Research (NCAER), New Delhi, on this research work. SANJIB POHIT is Senior Economist, NCAER, ALAN V. DEARDORFF and ROBERT M. STERN are both Professors of Economics and Public Policy, University of Michigan, Ann Arbor. The authors wish to thank N. Sangeeta and Alan Fox for their able research assistance. The research underlying the paper was funded by the US Agency for International Development (USAID), New Delhi. 


\section{POLICY RELEVANCE}

India entered into an era of ambitious industrialisation during the mid-1950s with the Mahalanobis strategy of development as its basis. The emphasis was on import substitution, heavy industries, and a central role for the public sector. Export pessimism was widely prevalent. The trade policy regime was highly protectionist and regulated through quantitative controls on imports, and tariff rates were exceptionally high. Domestic industry, heavily insulated from international competition, was under strict regulation.

A beginning was made towards liberalisation of India's trade policy regime during the late 1970s, and this liberalisation gained some momentum during the latter half of the 1980s. The Committees led by P.C. Alexander (1977), Abid Hussain (1984), and Narasimham (1985) influenced Indian thinking on trade policy reform by emphasising two major points: (1) there was a need to develop an efficient system which would make exports less costly and more profitable; and (2) there was a need to move away from a discretionary system of quantitative import controls to a system based on tariffs. The Long Term Fiscal Policy, announced in 1985, envisaged the eventual removal of import licensing from all imports except consumer goods and also proposed simplification of the complex tariff structure. Quantitative restrictions were in fact being gradually removed along with expansion in the open general licence (OGL) list of imports. The imports of various capital goods and MW materials became freer as these were put on the OGL list along with reduction in their tariff rates. However, the changes that took place up to July 1991 were quite small by comparison with what was needed. The dominant view continued to be that if a good could be produced in India, then it should be protected from import competition irrespective of its cost of production. Thus, despite all these measures, the Indian economy remained a highly protected economy at the end of the 1980s (see World Bank, 1989).

India commenced its major thrust towards globalisation in July 1991, triggered by the pressure of crisis in its external sector and a concurrent fiscal deficit. A programme of macroeconomic stabilisation was initiated through reducing the fiscal deficit, controlling the money supply, and correcting the overvalued currency by a major devaluation of the rupee. The rupee was subsequently made partially convertible in 1992-93, fully convertible on trade account in 1993-94, and fully convertible on current account in 1994-95. Many overdue microeconomic/sectoral reforms with a medium-term perspective were also launched. Major structural reforms were introduced in the industrial and trade policy regimes and in the financial sector with a view to improving the efficiency, productivity and international competitiveness of India's manufacturing sector. ${ }^{1}$

${ }^{1}$ For additional details, see Bhagwati and Srinivasan (1993) and Joshi and Little (1994). 
It has now become widely accepted that, in order to achieve the desired results, India has to transform itself into an internationally competitive economy open to trade and foreign investment. Significant changes in the industrial policy regime have already led to industrial delicensing and a larger role for the private sector. Changes in trade policy have involved abolishing import licensing (except for imports of consumer goods) as well as reductions in import duties. Reforms have also been initiated towards streamlining the structure of indirect taxes in India. With these trade and industrial policy reforms, India has entered a new era with a more competitive industrial environment in which entrepreneurs are expected to respond more to the signals of the market than to bureaucratic controls and the need to skirt around them.

The economy appears to have responded well to the ongoing process of economic reforms. GDP has grown by more than 6.5 per cent per annum between 1992 and 1997. The Central Government's fiscal deficit as a proportion of GDP has declined significantly. The rate of gross domestic savings has risen substantially. The average rate of inflation has been below double digits. Both exports and imports have grown significantly faster during this period. ${ }^{2}$

The issues that we will analyse below have immense policy relevance for India. For example, Indian policy makers need to know the likely direction of inter-sectoral changes that would result when India undertakes unilateral trade and industry policy reforms and its industrial structure becomes more internationally competitive. The analysis may also help to identify the relative strengths of sectors in making decisions with regard to future investments and the implications for expanding and contracting sectors in terms of employment.

\section{THE DISTINGUISHING FEATURES OF THE CGE MODEL OF INDIA}

The CGE model that we have developed is distinctly different from existing models of the Indian economy. Our India Model is a single-country, multisectoral CGE model. While it is patterned after the structure used in the Michigan world trade CGE model developed by Brown, Deardorff, and Stern (BDS) and applied in a variety of their papers, ${ }^{3}$ it contains a number of special features that are unique to the structure of the Indian economy. In what follows, we describe briefly the distinguishing features of our model. The technical details and equations of the model are available in Chadha et al. (1996a and 1997).

In line with the BDS model, the present model incorporates some of the features of the new trade theory, viz. increasing returns to scale, monopolistic

\footnotetext{
${ }^{2}$ Details on India's post-1991 economic performance are to be found in Economic Survey (199697). See also Joshi and Little (1996).

${ }^{3}$ Recent examples include Brown, Deardorff and Stern (1995 and 1996) and Brown, Deardorff, Djankov and Stern (1996).
} 
TABLE 1

Sectoral Breakdown of India CGE Model: Key Economic Indicators (Rs. million, 1989-90)

\begin{tabular}{|c|c|c|c|c|c|c|c|}
\hline & Sector & $\begin{array}{l}\text { ISIC } \\
\text { Code }\end{array}$ & $\begin{array}{l}\text { Market } \\
\text { Structure }\end{array}$ & Output & Exports & Imports & $\begin{array}{l}\text { Labour } \\
\text { Share }\end{array}$ \\
\hline 1. & Paddy & $1 \mathrm{~A}$ & $\mathrm{PC}, \mathrm{AP}$ & 305273 & 3836 & 2829 & 0.1717 \\
\hline 2. & Wheat & IB & PC, AP & 153795 & 19 & 214 & 0.1272 \\
\hline 3. & Other cereals & IC & $\mathrm{PC}$ & 75988 & 19 & 235 & 0.1717 \\
\hline 4. & Other agriculture & ID & $\mathrm{PC}$ & 1274741 & 25118 & 12999 & 0.1654 \\
\hline 5. & $\begin{array}{l}\text { Food, Beverages \& } \\
\text { Tobacco }\end{array}$ & 310 & MC & 347930 & 10914 & 5061 & 0.0253 \\
\hline 6. & Textiles & 321 & $\mathrm{MC}$ & 519963 & 23770 & 3557 & 0.0223 \\
\hline 7. & Clothing & 322 & MC & 88864 & 43206 & 659 & 0.0016 \\
\hline 8. & Leather products & 323 & $\mathrm{MC}$ & 17917 & 10021 & 237 & 0.0008 \\
\hline 9. & Footwear & 324 & $\mathrm{MC}$ & 18285 & 5297 & 77 & 0.0007 \\
\hline 10. & Food products & 331 & $\mathrm{MC}$ & 24281 & 138 & 351 & 0.0011 \\
\hline 11. & Furniture and fixtures & 332 & $\mathrm{MC}$ & 3471 & 3 & 0 & 0.0001 \\
\hline 12. & Paper and paper products & 341 & $\mathrm{MC}, \mathrm{AP}$ & 49211 & 158 & 9678 & 0.0021 \\
\hline 13. & Printing and publishing & 342 & $\mathrm{MC}$ & 36711 & 90 & 975 & 0.0022 \\
\hline 14. & Fertilizer & $35 \mathrm{~A}$ & $\mathrm{MC}, \mathrm{AP}$ & 62294 & 15 & 12279 & 0.0015 \\
\hline 15. & Other chemicals & $35 \mathrm{~B}$ & $\mathrm{MC}$ & 253450 & 16029 & 43932 & 0.0067 \\
\hline 16. & $\begin{array}{l}\text { Petroleum \& related } \\
\text { products }\end{array}$ & $35 \mathrm{C}$ & $\mathrm{MC}, \mathrm{SM}$ & 173382 & 5303 & 15323 & 0.0009 \\
\hline 17. & Rubber products & 355 & $\mathrm{MC}$ & 45742 & 6765 & 629 & 0.0017 \\
\hline 18. & $\begin{array}{l}\text { Non-metallic mineral } \\
\text { products }\end{array}$ & $36 \mathrm{~A}$ & $\mathrm{MC}$ & 58917 & 29076 & 178 & 0.0060 \\
\hline 19. & Glass and glass products & 362 & $\mathrm{MC}$ & 49087 & 23298 & 1534 & 0.0001 \\
\hline 20. & Iron and steel & 371 & SM & 177158 & 2258 & 30619 & 0.0065 \\
\hline 21. & Non-ferrous metals & 372 & $\mathrm{MC}$ & 37334 & 906 & 14059 & 0.0027 \\
\hline 22. & Metal products & 381 & $\mathrm{MC}$ & 66688 & 1093 & 12766 & 0.0035 \\
\hline 23. & $\begin{array}{l}\text { Non-electrical } \\
\text { machinery }\end{array}$ & 382 & MC & 135705 & 13033 & 90594 & 0.0073 \\
\hline 24. & Electrical machinery & 383 & $\mathrm{MC}$ & 168684 & 10060 & 33494 & 0.0057 \\
\hline 25. & Transport equipment & 384 & MC & 161818 & 7213 & 21404 & 0.0093 \\
\hline 26. & Misc. manufactures & $38 \mathrm{~A}$ & $\mathrm{MC}$ & 120160 & 5338 & 14019 & 0.0032 \\
\hline 27. & Mining and quarrying & 2 & SM & 130772 & 4988 & 95098 & 0.0080 \\
\hline 28. & Electricity, gas \& & & & & & & \\
\hline & water sup & 4 & SM & 215171 & 67 & 0 & 0.0038 \\
\hline 29. & Construction & 5 & $\mathrm{PC}$ & 561964 & 8449 & 4119 & 0.0403 \\
\hline 30. & Wholesale \& retail trade & 6 & $\mathrm{PC}$ & 614688 & 56046 & 9393 & 0.0747 \\
\hline 31. & Rail transport & $7 \mathrm{~A}$ & SM & 100802 & 0 & 0 & 0.0061 \\
\hline 32. & $\begin{array}{l}\text { Other transp. Storage \& } \\
\text { commn. }\end{array}$ & 7B & $\mathrm{PC}$ & 365920 & 42615 & 48712 & 0.0220 \\
\hline 33. & Financial services & 8 & $\mathrm{PC}$ & 405957 & 7042 & 3799 & 0.0084 \\
\hline 34. & Personal services & 9 & $\mathrm{PC}$ & 761316 & 5877 & 207 & 0.0886 \\
\hline
\end{tabular}

Notes:

* PC: Perfect Competition; MC: Monopolistic Competition; AP: Administered Price; SM: State Monopoly. Sectors under SM have administered prices.

** The total labour force in 1989-90 was 295 million. This column indicates the fraction of sectoral employment.

Source: Chadha, Pohit, Deardorff and Stern (1997). 
competition and product heterogeneity. India is modelled to produce, consume and trade 33 tradable goods. In addition, there is one non-traded sector, rail transport. The sectoral breakdown, as shown in Table 1, has been concorded from India's classification system to ISIC Rev.2. Table 1 also presents some of the key sectoral economic indicators of the Indian economy in the year 1989-90 together with specification of the market structure for different sectors.

The market structure in 29 of the 34 sectors is modelled as either perfectly competitive or monopolistically competitive, depending on the degree of scale economies in production. The remaining five sectors are assumed to be state monopolies, including the non-traded rail transport sector. Out of 33 tradable sectors, nine are assumed to be under perfect competition and four under state monopolies. The remaining sectors are assumed to be under monopolistic competition, except for three sectors in which prices are administered.

The final demand equations for various sectors are obtained assuming a single representative consumer who maximises utility subject to a budget constraint. The revenue from tariffs and indirect taxes along with profits of the state monopoly sectors are assumed to be redistributed to consumers and spent. Intermediate demands are derived from the profit-maximising decisions of the representative firms in each sector. Products in all the tradable sectors are assumed to be characterised by some degree of product differentiation. In the nine sectors where markets are taken to be perfectly competitive, as well as in the cases of four state monopoly sectors and three administered-price manufacturing sectors, products are differentiated by country of origin, i.e., whether from India or rest-of-world (ROW). In the monopolistically competitive industries, products are differentiated by firm. India is assumed to be a small country so that world prices of various tradable goods are exogenous.

Consumers and producers are assumed to use a two-stage procedure to allocate expenditure across differentiated products. At the first stage, expenditure is allocated across goods without regard to the country of origin (whether India or ROW) or the producing firm. At this stage, the utility function is taken to be Cobb-Douglas and the production function requires intermediate inputs in fixed proportion. In the second stage, expenditure on monopolistically competitive goods is allocated across competing firms in India and ROW. However, in the case of perfectly competitive goods, since individual firm supply is indeterminate, expenditure on each good is allocated over the industry as a whole. The aggregation function in the second stage is a Constant Elasticity of Substitution (CES) function.

With respect to factor markets, the variable input requirements are taken to be the same for the three market structures. Primary and intermediate input aggregates are required in fixed proportion to output. ${ }^{4}$ Expenditures on primary

\footnotetext{
${ }^{4}$ Intermediate inputs include both domestic and imported varieties.
} 
inputs are allocated between capital and labour, assuming that a CES function is used to form the aggregate of these primary inputs. In the case of the four agricultural sectors, land (along with capital and labour) is also assumed to be one of the primary factors of production. The primary inputs aggregate in these cases is a CES function of labour and a CES composite of land and capital. In the monopolistically competitive sectors as well as in the state monopoly sectors, additional fixed inputs of capital and labour are required. It is assumed that fixed capital and fixed labour are used in the same proportion as variable capital and variable labour so that production functions are homothetic. Capital and labour are assumed to be perfectly mobile across sectors, except that all capital is assumed to be immobile into and out of the state monopoly sectors. However, we keep the option of specifying sector-specific capital for some purposes, especially for short-term analysis. Land usage in agriculture is assumed to be substitutable across the four agricultural sectors. Returns to land, capital (in sectors across which it is mobile), and labour are determined to equate factor demand to an exogenous supply of each factor. The aggregate supplies of labour, capital, and agricultural land are assumed to remain fixed so as to abstract from macroeconomic considerations involving, for example, determination of investment, since our focus is on the intersectoral allocation of resources.

Perfectly competitive firms are assumed to set price equal to marginal cost, while monopolistically competitive firms maximise profits by setting price as an optimal markup over marginal cost. The numbers of firms in sectors under monopolistic competition are determined by the condition that there are zero profits. The numbers of firms in the state monopoly sectors as well as in the three administered price sectors under imperfect competition are assumed to remain fixed.

India's merchandise imports are subject to tariffs and non-tariff barriers (NTBs). NTBs are incorporated by endogenously solving for the ad valorem tariffequivalent rate that would hold imports within each product category covered by NTBs at a pre-determined level. An ad valorem tariff variable in each product category is then an average of this NTB tariff-equivalent rate and the nominal tariff rate, using the NTB coverage ratio to weight the NTB tariff equivalent. Tariff rates are aggregated according to the sectors specified in Table 1.

In the non-tradable rail transport sector, total demand must equal national output. The price in this sector is assumed to be set by the government and hence exogenous. For two of the four agricultural sectors, viz. other cereals and rest of agriculture (which are under perfect competition), total demand (inclusive of exports) for the sector's product must equal its output. In the case of the remaining two agricultural sectors, paddy and wheat, as well as in four tradable state monopoly sectors, the prices are assumed to be administered by the government. In three of the sectors under imperfect competition, viz. paper products, fertilisers and non-ferrous metals, the prices have been assumed to be administered. 
In our model we assume that aggregate expenditure varies endogenously to hold aggregate employment constant. Such a closure may be thought of as analogous to the Johansen closure rule (see Deardorff and Stern, 1990). The Johansen closure rule consists of keeping the requirement of full employment while dropping the consumption function. This means that consumption can be thought of as adjusting endogenously to ensure full employment. However, in the present model, we do not distinguish consumption from other forms of final demand. That is, we assume that expenditure adjusts to maintain full employment which may be thought of as analogous to the Johansen closure rule.

The reference year of the model is 1989-90. In order to investigate sectoral employment effects of the unilateral trade liberalisation, it has been assumed that the existing bilateral tariffs will be removed and NTBs will be relaxed in two stages to be noted below. The domestic policy inputs include reduction in other net indirect taxes (indirect taxes net of custom duty and subsidies) and changes in administered prices in the regulated sectors. ${ }^{5}$ All of the data used come from official Indian Government sources and are available in Chadha et al. (1996b and 1997).

Our model requires estimates of various types of elasticity measures, viz. demand elasticities of exports and imports and elasticities of substitution between factors of production and between varieties of goods. Similar to other CGE models, most of our estimates are based on the published literature, although we have estimated elasticities of substitution between labour and capital in various sectors in Chadha, Pohit, and Bina (1995).

Our model is solved using GEMPACK (Harrison and Pearson, 1996). When policy changes are introduced into the model, the method of solution yields percentage changes in sectoral employment and certain other variables of interest for India. Multiplying the percentage changes by actual (1989-90) levels given in the data base yields the absolute changes, positive or negative, that might result from India's unilateral trade and domestic policy reforms.

In addition to the sectoral effects that are the primary focus of our analysis, the model also yields results for changes in total exports, total imports, the terms of trade, the overall level of welfare in the economy, and the economy-wide changes in real wages and returns to capital. Because both labour and capital are assumed to be homogeneous and intersectorally mobile in these scenarios, ${ }^{6}$ we cannot distinguish effects on factor prices by sector. Nor can we distinguish effects on different skill groups or other categories of labour. Though we would like to know more about the distributional issues associated with the reforms, the model

\footnotetext{
${ }^{5}$ It should be noted that India's indirect taxes are commodity taxes and other indirect taxes. The commodity taxes include excise duties, sales taxes, custom duties (both exports and imports) and various other duties. The other indirect taxes include levies, such as those on electricity, motor vehicles, entertainment tax, stamp duty, etc.

${ }^{6}$ The capital stock is assumed to remain fixed in the state monopoly sectors.
} 
in its present form is not set up to accomplish this. Our model also does not account for changes in foreign direct investment, and it does not make any allowance for dynamic efficiency changes and economic growth. ${ }^{7}$

\section{THE SCENARIOS}

We focus in particular on changes in tariffs and NTBs under three alternative assumptions: (1) the economy retains certain product market imperfections (state monopolies and administered prices) as these existed in 1989-90; (2) the economy is free from such distortions; and (3) the economy is free from such distortions and an attempt is also made to rationalise the indirect-tax regime. Our computational analysis includes the following aspects of the reforms:

(i) Import Reforms: these refer to reductions in tariffs and NTBs on imports;

(ii) Import and Export Reforms: these refer to the above mentioned import reforms plus reduction in NTBs on exports.

The first set of simulations refers to trade liberalisation while retaining the product market imperfections. The state monopolies and the administered-price sectors continue to operate in the same way. The domestic policy reforms are thus assumed to maintain the status quo. We refer to this as the 'administered version' of the model. The results of such analysis are thus based on the assumption that domestic policy with respect to the product market imperfections remains unchanged.

The second set of simulations refers to trade liberalisation under the assumption that the domestic reforms have already taken place. We refer to this as the 'market version' of the model. It is assumed that before we introduce trade reforms, as indicated above, the economy has already removed the product market imperfections. Thus all the sectors that were under state monopoly in 1989-90 are assumed to have been opened up to private competition, such that petroleum products and iron and steel operate under monopolistic competition, while mining and quarrying, electricity, gas and water, and rail transport operate under perfect competition. Accordingly, the prices are no longer taken to be 'administered' in these sectors. We also assume that the sectors that were under some kind of administered price regime in 1989-90 now determine their own prices. This amounts to doing away with administered prices in two agricultural sectors, viz. paddy and wheat, and in three manufacturing sectors, viz. paper products, fertiliser, and

\footnotetext{
${ }^{7}$ See Martin and Winters (1996), especially Chs 8 and 9, for CGE studies of the Uruguay Round negotiations that include discussion and estimates of the effects of dynamic efficiency and economic growth. Francois and Reinert (1997) also contains some useful discussion and illustrations of these issues.
} 
non-ferrous metals. The paddy and wheat sectors are assumed to be perfectly competitive while the three manufacturing sectors are assumed to be monopolistically competitive. Further, domestic capital is mobile across all sectors.

The third set of simulations refers to trade liberalisation under the "market version' of the model along with reducing subsidies (through increasing other net indirect taxes) in the agricultural sectors, fertiliser, and electricity, gas and water supply, and also reducing excise duties (through reducing net indirect taxes) on the remaining sectors of the Indian economy. Thus, these changes in indirect taxes are superimposed on the experiments with import and export liberalisation under the domestically liberalised economy (market version) as discussed above in the second set of simulations.

Of course, the policy inputs to the various simulations are guided by our assumptions regarding the extent of the trade policy reforms, to which we now turn.

\section{a. Reduction in Import Duties}

As noted in Table 2, the import-weighted-average declared duty is to be reduced from 87 per cent in 1989-90 to 45 per cent in 1995-96 and to 25 per cent in 1998-99. The reduction to 25 per cent may even be achieved by $1997-$ 98.

The collection rate was 50.4 per cent in 1989-90. It came down to 29 per cent in 1994-95, and it may go down further to 25 per cent by 1998-99. We refer to the period, 1989-90 to 1995-96, as Stage I and the longer period 198990 to $1998-99$ as Stage II. Note that Stage II includes Stage I and extends beyond it.

TABLE 2

Proposed Tariff Rates by Major Sectors

\begin{tabular}{|c|c|c|c|c|}
\hline \multirow{2}{*}{ Sectors } & \multirow{2}{*}{$\begin{array}{l}\text { Import } \\
\text { Weight }\end{array}$} & \multicolumn{3}{|c|}{ Import Weighted Average } \\
\hline & & 1989-90 & 1995-96 & 1998-99 \\
\hline Agricultural Products & 0.03 & 46 & 20 & 15 \\
\hline Coal, crude oil natural gas & 0.16 & 54 & 34 & 25 \\
\hline Other mineral products & 0.03 & 20 & 15 & 10 \\
\hline Manufactured products & 0.78 & 98 & 49 & 25 \\
\hline Consumer goods & 0.07 & 89 & 60 & 50 \\
\hline Intermediate Goods & 0.47 & 103 & 45 & 30 \\
\hline Capital goods & 0.24 & 91 & 55 & 30 \\
\hline Import Weighted Average & 1.00 & 87 & 45 & 25 \\
\hline
\end{tabular}

Source: Adapted from Tariff Reforms Committee (Chelliah Committee) Interim Report (1991) (Table 8.2 and para 8.47) and Final Report-II (para 2.11). 


\section{b. Reduction in NTBs on Imports}

The existing NTBs (1989-90) on imports are assumed to be partially relaxed so as to permit a specified per cent increase in the imports that had been constrained. This is implemented in the model by increasing the level of imports that were under some kind of quantitative restriction for the sectors subject to import NTBs. Handling NTBs in such a manner is not altogether satisfactory, but our rationale is that the existing NTBs are not expected to be completely eliminated at the end of Stage II.

The estimated increases in imports from relaxation of NTBs are noted in Table 3. While these estimates are not based on any actual declared numbers, we have tried to incorporate the implicit intentions in various policy announcements whereby the imports of agricultural and consumer goods are tikely to remain more restricted than those of intermediate and capital goods as well as services. Thus, these estimates are indicative of the government's intentions towards the degree of expansion of imports that were under some type of quantitative restriction in 1989-90.

\section{c. Export Reforms}

Export taxes were negligible in 1989-90. The existing NTBs (1989-90) on exports are assumed to be partially relaxed so as to permit a specified per cent increase in the exports that had been constrained. This is implemented in the model by increasing the level of exports that were under some kind of quantitative restriction for the sectors subject to export NTBs. Again, we have assumed here that the NTBs on exports are not expected to be completely removed as of Stage II. The estimated increases are noted in Table 4.

TABLE 3

Per Cent Increases (over 1989-90) in the Level of Imports under NTBs

\begin{tabular}{lcc}
\hline Sectors & $1995-96$ & $1998-99$ \\
\hline Agricultural Goods & 10 & 25 \\
Consumer Goods & 25 & 50 \\
Intermediate Goods & 75 & 85 \\
Capital Goods & 75 & 85 \\
Services & 75 & 85 \\
\hline
\end{tabular}

Source: Our estimates

TABLE 4

Per Cent Increases (over 1989-90) in Constrained Exports

\begin{tabular}{lcc}
\hline Sectors & $1995-96$ & $1998-99$ \\
\hline Agricultural sectors & 25 & 50 \\
Other sectors & 50 & 75 \\
\hline
\end{tabular}

Source: Our estimates. 
TABLE 5

Per Cent Change (over 1989-90) in Tax/Subsidy Rates

\begin{tabular}{lcc}
\hline Sectors & $1995-96$ & 1998-99 \\
\hline Reduction of subsidies to four agricultural sectors, & & 10 \\
fertiliser, and electricity, gas and water supply & 5 & 10 \\
Reduction of indirect taxes in 28 other sectors & 5 & \\
\hline
\end{tabular}

Source: Our estimates.

As with imports, these estimates are based on the government's stated policy of expanding exports of agricultural goods at a slower rate compared to other sectors.

\section{d. Rationalisation of Indirect Taxes}

In this paper, we have not undertaken a detailed analysis of the sectoral impacts of changes in the excise duty structure as envisaged in The Tax Reforms Committee (TRC), chaired by Raja J. Chelliah. Instead we have performed a simple experiment for indirect tax rationalisation, which is that the rates of subsidies (negative net indirect taxes) are reduced in each of the four agricultural sectors, the fertiliser sector, and in electricity, gas and water supply. In all the remaining 28 sectors, the indirect taxes are assumed to be reduced through reduction in rates of excise duties. These changes are noted in Table 5. For example, a 10 per cent reduction in the base year net indirect tax rate of say, 15 per cent, would imply a 1.5 per cent points reduction in the net indirect tax rate of 15 per cent.

\section{RESULTS}

It is expected that trade liberalisation will stimulate production especially in the labour-intensive sectors in India. Productive resources will then be allocated more efficiently as compared to the preliberalisation position, as India specialises in the production of tradable goods in which it has comparative advantage. There may of course be transitional costs due to the intersectoral movement of factors of production, but we do not take them into account. Beyond the conventional welfare gains, trade liberalisation is also expected to have a 'pro-competitive' effect on domestic firms, resulting in additional gains from the realisation of economies of scale in production. That is, when firms are protected by tariffs and NTBs from foreign competition, they may take advantage of their market power by raising prices and reducing domestic sales. The result is that the protected firms may produce at levels below their minimum-cost plant size. Trade liberalisation should then bring about competitive pressures on formerly protected firms and induce them to raise production and productivity and to 
achieve more efficient plant size and lower per unit costs. Thus the gains in economic welfare are expected to come from improved allocation of resources, lower prices to consumers and business firms, and availability of more varieties to consumers. The realisation of economies of scale in manufacturing reinforces these welfare-enhancing effects.

The gains from the liberalisation scenarios under study should, however, be interpreted in the light of the assumptions of our modelling structure. In particular as already noted, we have abstracted from the effects of macroeconomic forces and policies, and we are not able to capture the effects of dynamic changes in efficiency and economic growth. We have also not analysed the effects of possible changes in inflows of foreign direct investment. Thus the reported gains are the result of reductions only in tariffs and NTBs along with the rationalisation of the structure of net indirect taxes and subsidies. Finally, we do not model the benefits to the Indian economy that may result from trade policy changes in India's major trading partners.

In the tables we report both of the overall changes in the Indian economy which our model attributes to the policy changes in the various scenarios, and also a number of sectoral effects on output and related variables, factors of production, and trade. Underlying and driving all these results are detailed changes in prices at the sectoral level which we do not report. Sectoral prices respond to changes in tariffs, NTBs, and the exchange rate, as well as interacting among themselves through linkages in supply and demand.

The reduction in import tariffs and NTBs leads to a decline in the sectoral tariff equivalents (tariff plus tariff equivalent of import NTBs), which are endogenously determined in the model. With import liberalisation, the Indian rupee will depreciate in order to keep the base-year balance of trade at the same level. Consequently, the sectoral export-tax equivalents (export tax plus export tax equivalent of export NTBs) tend to increase. World prices are assumed to be exogenous. Therefore, the changes in import prices depend on two opposing forces, viz. the declining import tariff equivalents which tend to make imports cheaper and the depreciating currency which tends to make imports costlier. However, the currency depreciation gets an opposing push from the increased demand for Indian goods by the ROW.

The changes in world prices of India's goods also depend on two opposing forces, viz. the increasing export-tax equivalents which tend to make exports costlier and the depreciating currency which tends to make exports cheaper. Consequently, the import prices as well as the domestic prices in most of the sectors decline, resulting in increases in exports as well as imports. If the export NTBs are also reduced, the export-tax equivalent moves downwards, thus giving rise to an additional increase in sectoral exports.

The domestic price charged by a representative firm declines in almost all the cases except for the four agricultural sectors (sectors 1 to 4 ) and the two services 
sectors (sectors 33 and 34). These are the sectors that have a very high value added content. Since all primary factors of production now have become more costly, the overall domestic price rises in these sectors. This increase in domestic prices of agricultural goods leads to improvement in the terms of trade in favour of agriculture. The domestic prices of wood products and furniture and fixtures also increase since these depend on now costlier raw materials (wood) from agriculture.

\section{a. Increase in GDP}

Tables 6 and 7 report overall (economy-wide) results for all scenarios first for the initial period as Stage I in Table 6, and then for the entire period, Stage II, in Table 7. It may be observed that the economy gains in GDP (a proxy for welfare) when trade policy reforms are undertaken. The gains in GDP increase as India proceeds with reductions in import restrictions to concurrent reductions in export restrictions (Table 6) during Stage I under the 'administered version' of the model. The gains increase noticeably when the economy undertakes such reforms under the 'market version' of the model. That is, the effect on GDP increases from 1.1 per cent with 'import reforms' under the 'administered version' to 3.1 per cent with 'import and export reforms' under the 'market version' of the model. GDP increases somewhat more if we rationalise the indirect tax regime. A similar picture emerges from the results reported in Table 7 for the longer period,

TABLE 6

Overall Changes from Unilateral Liberalisation - Stage I (1989-90 to 1995-96)

\begin{tabular}{|c|c|c|c|c|c|}
\hline & \multicolumn{2}{|c|}{$\begin{array}{c}\text { Trade Reforms } \\
\text { (Administered Version) }\end{array}$} & \multicolumn{2}{|c|}{$\begin{array}{l}\text { Trade and Domestic } \\
\text { Policy Reforms } \\
\text { (Market Version) }\end{array}$} & \multirow{2}{*}{$\begin{array}{c}\text { Trade and Domestic } \\
\text { Policy Reforms and } \\
\text { Indirect Tax } \\
\text { Rationalisation }\end{array}$} \\
\hline & $\begin{array}{l}\text { Import } \\
\text { Reforms }\end{array}$ & $\begin{array}{c}\text { Import and } \\
\text { Export } \\
\text { Reforms }\end{array}$ & $\begin{array}{r}\text { Import } \\
\text { Reforms }\end{array}$ & $\begin{array}{l}\text { Import and } \\
\text { Export } \\
\text { Reforms }\end{array}$ & \\
\hline GDP & 1.07 & 1.35 & 2.32 & 3.13 & 3.23 \\
\hline \multicolumn{6}{|l|}{ Returns } \\
\hline Land & 1.00 & 1.55 & 2.32 & 3.19 & 3.23 \\
\hline Labour & 1.62 & 1.88 & 2.80 & 3.40 & 3.63 \\
\hline Capital & 1.471 & 1.66 & 2.87 & 3.34 & 3.77 \\
\hline \multicolumn{6}{|l|}{ Currency } \\
\hline Depreciation & 27.82 & 22.09 & 29.59 & 22.39 & 22.21 \\
\hline $\begin{array}{l}\text { Terms of Trade } \\
\text { (Agr. vs Mfg.) }\end{array}$ & 2.20 & 2.40 & 4.60 & 5.74 & \\
\hline
\end{tabular}


TABLE 7

Overall Changes from Unilateral Liberalization - Stage II (1989-90 to 1998-99)

\begin{tabular}{|c|c|c|c|c|c|}
\hline & \multicolumn{2}{|c|}{$\begin{array}{c}\text { Trade Reforms } \\
\text { (Administered Version) }\end{array}$} & \multicolumn{2}{|c|}{$\begin{array}{l}\text { Trade and Domestic } \\
\text { Policy Reforms } \\
\text { (Market Version) }\end{array}$} & \multirow{2}{*}{$\begin{array}{c}\text { Trade and Domestic } \\
\text { Policy Reforms and } \\
\text { Indirect Tax } \\
\text { Rationalisation }\end{array}$} \\
\hline & $\begin{array}{r}\text { Import } \\
\text { Reforms }\end{array}$ & $\begin{array}{l}\text { Import and } \\
\text { Export } \\
\text { Reforms }\end{array}$ & $\begin{array}{l}\text { Import } \\
\text { Reforms }\end{array}$ & $\begin{array}{l}\text { Import and } \\
\text { Export } \\
\text { Reforms }\end{array}$ & \\
\hline GDP & 1.60 & 2.01 & 3.38 & 5.00 & 5.15 \\
\hline \multicolumn{6}{|l|}{ Returns } \\
\hline Land & 1.26 & 2.24 & 2.89 & 4.57 & 4.64 \\
\hline Labour & 2.19 & 2.58 & 3.62 & 4.70 & 5.16 \\
\hline Capital & 2.11 & 2.36 & 3.85 & 4.64 & 5.53 \\
\hline \multicolumn{6}{|l|}{ Currency } \\
\hline Depreciation & 38.29 & 29.57 & 38.21 & 26.63 & 26.33 \\
\hline $\begin{array}{l}\text { Terms of Trade } \\
\text { (Agr. vs Mfg.) }\end{array}$ & 2.80 & 3.20 & 5.60 & 6.10 & 7.10 \\
\hline
\end{tabular}

Stage II. Thus, India's real GDP has the potential of increasing by as much as five per cent when allowance is made for further liberalisation.

\section{b. Gains in Returns to Factors of Production}

The gains to the economy are also reflected in higher real returns to all three factors of production. It is evident from Tables 6 and 7 that all factors gain in real terms by nearly the same proportion as the percentage increase in GDP. Thus, contrary to the Stolper-Samuelson theorem, even the scarce factors of production (land and capital), gain when tariffs against imports are lowered. ${ }^{8}$ This is an important finding in the context of the Indian economy where capital as well as land are scarce resources.

The returns to the individual factors increase between 1.0 and 1.5 per cent when the economy reduces import tariffs and NTBs under the 'administered version' of the model and between 3.2 and 3.4 per cent when the economy undertakes trade reforms under the 'market version'. The factor returns increase further when we rationalise the indirect tax regime.

A similar picture emerges from the results reported in Table 7 (Stage II). Thus, the real returns to the factors of production may rise by more than 4.5 per cent as a result of the various trade and domestic policy reforms that have been analysed.

${ }^{8}$ For a theoretical treatment of the forces that may counteract the Stolper-Samuelson theorem, see Brown, Deardorff and Stern (1993). 


\section{c. Terms of Trade Between Agriculture and Manufacturing}

One of the implications of the reform process relates to the domestic terms of trade between agriculture and industry. The tariff reductions and deregulation in the industrial sector are expected to change the terms of trade between agriculture and industry in favour of agriculture (Gulati and Chadha, 1995). This is borne out in Tables 6 and 7, with the effect becoming larger with the widening of reforms. The shift of the terms of trade in favour of agriculture varies from 2.2 per cent when the economy undertakes import reforms under the 'administered version' of the model (Table 6, column 1) to 6.1 per cent when the economy undertakes import and export reforms under the 'market version'.

\section{d. Output, Number of Firms, and Scale Effects}

The percentage changes in sectoral output, number of firms and 'scale effects' (output per firm) are given in Table 8. We report such changes only for the longer period, Stage II. The largest per cent change in output occurs in clothing, followed closely by leather products. Output increases also in: nonmetallic mineral products and glass products. This is the case in all the scenarios under the 'market version.' The sectors in which output declines include: non-ferrous metals; non-electrical machinery; and mining and quarrying. There are output declines as well in: paper products; fertiliser; iron and steel; metal products; electrical machinery; transport equipment; and transport, storage and communications services. The output of cereals declines while that of the rest of agriculture increases. Overall agricultural output, however, increases.

The change in the number of firms has been analysed only for the 22 monopolistically competitive manufacturing sectors and reflects the changes in the direction of output of the different sectors. The scale effect, which indicates the per cent change in the output per firm, is throughout. The largest scale effect is observed in the footwear sector, in which output per firm increases by about nine per cent under the import and export reforms of Stage II. This is followed by petroleum products and glass products where the scale effects are close to six per cent, and clothing, leather products, fertiliser and nonmetallic mineral production where the scale effects are between four and five per cent. Smaller scale effects are observed in: textiles; paper products; other chemicals; rubber products; and non-ferrous metals. While the scale effect turns out to be substantial for a few sectors that are relatively labour intensive, this is less true for the capital intensive sectors. Iron and steel, non-electrical machinery, electrical machinery, and transport equipment experience only one per cent increases in the scale effect. 
TABLE 8

Changes in Output, Number of Firms, and Scale Effects - Stage II

\begin{tabular}{|c|c|c|c|c|c|c|c|c|c|c|}
\hline \multirow{2}{*}{ SN Sectors } & \multirow{2}{*}{ ISIC } & \multicolumn{6}{|c|}{$\begin{array}{c}\text { Trade and Domestic Policy Reforms } \\
\text { Market Version }\end{array}$} & \multicolumn{3}{|c|}{$\begin{array}{c}\text { Trade and Domestic Policy } \\
\text { Reforms and Indirect Tax } \\
\quad \text { Rationalisation } \\
\text { Import \& Export Reforms }\end{array}$} \\
\hline & & Output & $\begin{array}{l}\text { No. of } \\
\text { Firms }\end{array}$ & $\begin{array}{l}\text { Scale } \\
\text { Effect }\end{array}$ & Output & $\begin{array}{l}\text { No. of } \\
\text { Firms }\end{array}$ & $\begin{array}{l}\text { Scale } \\
\text { Effect }\end{array}$ & Output & $\begin{array}{l}\text { No. of } \\
\text { Firms }\end{array}$ & $\begin{array}{l}\text { Scale } \\
\text { Effect }\end{array}$ \\
\hline 1. Paddy & IA & -1.3 & & & 1.1 & & & -1.5 & & \\
\hline 2. Wheat & IB & -1.1 & & & -1.4 & & & -2.0 & & \\
\hline 3. Other Cereals & IC & -1.4 & & & -1.7 & & & -1.9 & & \\
\hline 4. Rest of Agriculture & ID & 1.3 & & & 1.7 & & & 1.6 & & \\
\hline 5. Food, Bev. \& Tobacco & 310 & 1.5 & 0.9 & 0.6 & 1.5 & 0.9 & 0.6 & 1.5 & 0.3 & 1.2 \\
\hline 6. Textiles & 321 & 16.5 & 13.7 & 2.8 & 17.3 & 14.3 & 3.0 & 17.3 & 13.5 & 3.8 \\
\hline 7. Clothing & 322 & 122.6 & 118.2 & 4.4 & 130.4 & 125.8 & 4.6 & 127.2 & 122.1 & 5.1 \\
\hline 8. Leather Products & 323 & 93.6 & 89.4 & 4.2 & 103.5 & 98.9 & 4.6 & 102.3 & 97.0 & 5.3 \\
\hline 9. Footwear & 324 & 64.6 & 56.5 & $8 . \mathrm{I}$ & 69.4 & 60.4 & 9.0 & 68.8 & 59.1 & 9.7 \\
\hline 10. Wood Products & 331 & 2.2 & 2.1 & 0.2 & 2.2 & 2.1 & 0.1 & 2.8 & 2.3 & 0.5 \\
\hline 11. Furniture Fixtures & 332 & -0.8 & -1.7 & 0.9 & -1.1 & -2.0 & 0.9 & 0.9 & -2.4 & 1.5 \\
\hline 12. Paper Products & 341 & -10.7 & -12.6 & I.9 & -11.2 & -13.3 & 2.1 & -10.6 & -13.8 & 3.2 \\
\hline 13. Printing \& Publishing & 342 & -1.3 & -2.5 & 1.2 & -1.6 & -2.9 & 1.3 & -1.2 & -3.7 & 2.4 \\
\hline 14. Fertiliser & $35 \mathrm{~A}$ & -10.7 & -14.5 & 3.9 & -10.8 & -15.0 & 4.3 & -11.0 & -16.2 & 5.1 \\
\hline 15. Other Chemicals & $35 \mathrm{~B}$ & 4.8 & -3.5 & 2.7 & -1.0 & -3.9 & 3.0 & 0.0 & -4.7 & 4.8 \\
\hline
\end{tabular}




\begin{tabular}{|c|c|c|c|c|c|c|c|c|c|c|c|}
\hline 16. & Petroleum Products & $35 \mathrm{C}$ & 6.8 & 1.3 & 5.5 & 8.3 & 2.5 & 5.8 & 9.9 & 0.7 & 9.3 \\
\hline 17. & Rubber Products & 355 & 16.3 & 13.5 & 2.7 & 17.9 & 15.0 & 3.0 & 19.0 & 14.3 & 4.7 \\
\hline 18. & Non-metallic Min. Prod. & $36 \mathrm{~A}$ & 54.3 & 50.2 & 4.0 & 61.2 & 56.9 & 4.3 & 61.2 & 55.9 & 5.3 \\
\hline 19. & Glass Products & 362 & 60.0 & 54.5 & 5.4 & 67.9 & 61.9 & 6.0 & 68.6 & 61.1 & 7.5 \\
\hline 20. & Iron \& Steel & 371 & -8.3 & -9.5 & 1.3 & -11.0 & -12.1 & 1.2 & -9.2 & -12.3 & 3.1 \\
\hline 21. & Non-ferrous Metal & 372 & -27.2 & -29.7 & 2.5 & -32.5 & -35.1 & 2.6 & -29.2 & -33.8 & 4.6 \\
\hline 22. & Metal Products & 381 & 4.5 & 4.9 & 0.4 & -6.4 & -6.7 & 0.3 & -5.0 & -7.0 & 2.0 \\
\hline 23. & Non-electrical Machinery & 382 & -25.4 & -26.2 & 0.9 & -30.6 & -32.4 & 0.8 & -27.6 & -30.2 & 2.6 \\
\hline 24. & Electrical Machinery & 383 & -4.8 & -5.9 & 1.1 & -5.8 & -6.9 & 1.1 & -3.9 & -7.1 & 3.2 \\
\hline 25. & Transport Equipments & 384 & 4.3 & -5.5 & 1.2 & 4.7 & -5.9 & 1.2 & -3.3 & -6.3 & 3.0 \\
\hline 26. & Misc. Manufacturing & $38 \mathrm{~A}$ & 3.8 & 2.3 & 1.6 & 3.9 & 2.2 & 1.6 & 5.2 & 1.5 & 3.8 \\
\hline 27. & Mining \& Quarrying & 2 & -27.5 & & & -25.9 & & & -24.5 & & \\
\hline 28. & E!ectricity, Gas \& Water & 4 & 2.3 & & & 2.3 & & & 2.7 & & \\
\hline 29. & Construction & 5 & 0.8 & & & 0.7 & & & 1.4 & & \\
\hline 30. & Wholesale \& Retail Trade & 6 & 2.6 & & & 2.4 & & & 2.5 & & \\
\hline 31. & Rail Transport & $7 \mathrm{~A}$ & 0.5 & & & 0.4 & & & 1.1 & & \\
\hline \multirow{2}{*}{32.} & Other Transport, Storage & & & & & & & & & & \\
\hline & \& Com & $7 \mathrm{~B}$ & -2.7 & & & -3.2 & & & -2.5 & & \\
\hline 33. & Finance, Ins. \& Real Est. & 8 & 0.7 & & & 0.9 & & & 0.9 & & \\
\hline 34. & Comm. Social \& Pers. Serv. & 9 & 0.2 & & & -0.4 & & & -0.2 & & \\
\hline
\end{tabular}




\section{e. IntersectoraI Movement of Labour and Capital}

The intersectoral movements of labour and capital are recorded in Table 9. Both labour and capital move into the sectors with increased output, and conversely. In agriculture, land, labour and capital move out of cereals into other agriculture. Comparing the output changes in Table 8 to the factor employment changes in Table 9, it appears that the realisation of economies of scale in India's manufacturing sector tends to raise the average product of both labour and capital.

\section{f. Exports}

The results for changes in exports and imports in the 33 traded sectors of the Indian economy are provided in Table 10. The largest export increases are in: textiles; clothing; footwear; iron and steel; electrical machinery; transport equipment; and misc. manufacturing. Smaller increases in exports occur in: food, beverages and tobacco; leather products; furniture; paper products; printing and publishing; fertiliser; petroleum products; rubber products; non-metallic mineral products; glass products; nonferrous metal; and mining and quarrying.

If domestic policy reforms are also undertaken along with trade policy reforms, the percentage increases in exports tend to be greater, especially in: clothing; footwear; textiles; leather products; non-metallic mineral products; and glass products. The exports of the agricultural sectors, fertiliser, petroleum products, and mining and quarrying show substantial increases in export growth when export NIBs are also reduced along with import liberalisation. This is true under both the administered and market versions of the model.

\section{g. Imports}

When the economy undertakes reforms in trade policy alone (administered version), the percentage increases in sectoral imports are substantial in: electrical machinery; transport equipment; wholesale and retail trade; other transport, storage and communications; and finance, insurance and real estate. The sectors in which imports decline include: clothing; community, social and personal services; wood products; iron and steel; and non-ferrous metals. Imports of rice and wheat also decline.

If the economy also undertakes domestic policy reforms along with trade policy reforms (market version), some of the sectors that showed reductions in imports under the administered version of the model are changed to import increases under the market version. These include: paper products; fertiliser; iron and steel; and non-ferrous metals. 


\section{SENSITIVITY ANALYSIS}

The model results have been tested for robustness by analysing their sensitivity to changes in some of the major parameters used in the model. These include: (1) demand elasticity of India's exports to ROW; (2) elasticity of substitution between imported and domestic varieties of goods produced by representative firms/industries in India; (3) elasticity of substitution between capital and labour in the non-agricultural sectors in India; (4) elasticity of substitution between land and capital in India's agricultural sectors; and (5) elasticity of substitution between labour and the composite of land and capital in India's agricultural sectors.

The details concerning the roles of these parameters in the model are discussed in Chadha et al. (1996 and 1997). The sensitivity results, which are not reported here, indicate that a ten per cent increase in export demand elasticity values for each of the tradable sectors leads to less than five per cent changes in effects on GDP, total imports, total exports, real returns to the three factors of production, and the currency depreciation. The major variables change by less than four per cent when the values of the elasticity of substitution between imported and domestic varieties are increased by ten per cent each. The model results remain even more stable with assumed ten per cent increases in the elasticities of substitution between the primary factors of production.

While these sensitivity experiments are somewhat informal, it appears that the model results are not particularly sensitive to the values of the major parameters used.

\section{CONCLUSION}

The Indian Governrnent has introduced significant unilateral macroeconomic and trade reforms since 1991-92. Under the import policy reforms, both tariffs and NTBs have been reduced. The economy has also been further opened up on the export side by reducing export barriers. The Indian rupee exchange rate has been made flexible subject to market forces. Furthermore, the domestic policy reforms have sought to eliminate or reduce various product market imperfections, such as state monopolies and administered prices in certain sectors of the economy. Finally, the structure of indirect taxes on production along with subsidies has been undergoing major reform.

In an effort to determine the economic effects of these various policy changes, we have constructed a multisectoral CGE model of the Indian economy. Our computational results suggest percentage increases in India's GDP of up to five per cent, depending on the full implementation of the reforms. We also show increased real returns to land, labour, and capital. The policy reforms appear to 
TABLE 9

Intersectoral Movement of Factors of Production - Stage II (Per cent)

\begin{tabular}{|c|c|c|c|c|c|c|c|c|c|c|c|}
\hline \multirow{3}{*}{ SN Sectors } & \multirow{3}{*}{$I S I C$} & \multicolumn{4}{|c|}{$\begin{array}{c}\text { Trade Reforms } \\
\text { Administered Version }\end{array}$} & \multicolumn{4}{|c|}{$\begin{array}{c}\text { Trade and Domestic Policy Reforms } \\
\text { Market Version }\end{array}$} & \multirow{2}{*}{\multicolumn{2}{|c|}{$\begin{array}{c}\text { Trade and Domestic } \\
\text { Policy Reforms and } \\
\text { Indirect Tax } \\
\text { Rationalisation } \\
\text { Overall }\end{array}$}} \\
\hline & & \multicolumn{2}{|c|}{ Import Reforms } & \multicolumn{2}{|c|}{$\begin{array}{l}\text { Import \& Export } \\
\text { Reforms }\end{array}$} & \multicolumn{2}{|c|}{ Import Reforms } & \multicolumn{2}{|c|}{$\begin{array}{c}\text { Import \& Export } \\
\text { Reforms }\end{array}$} & & \\
\hline & & Labour & Capital & Labour & Capital & Labour & Capital & Labour & Capital & Labour & Capital \\
\hline 1. Paddy & $1 \mathrm{~A}$ & -0.6 & -0.5 & -0.3 & 0.1 & -1.3 & -0.6 & -1.0 & -0.2 & -1.5 & 0.9 \\
\hline 2. Wheat & $1 \mathrm{~B}$ & -0.7 & -0.6 & -0.8 & -0.5 & -1.2 & -0.5 & -1.4 & -0.6 & -2.0 & -1.5 \\
\hline 3. Other Cereals & $1 \mathrm{C}$ & -1.1 & -1.1 & -1.2 & -1.2 & -1.5 & -0.8 & -1.7 & -0.9 & -1.9 & -1.4 \\
\hline 4. Rest of Agriculture & $1 \mathrm{D}$ & -1.1 & 0.9 & 1.5 & 1.6 & 1.3 & 2.0 & 1.8 & 2.6 & 1.6 & 2.2 \\
\hline 5. Food, Bev. \& Tobacco & 310 & 1.3 & 1.2 & 1.3 & 1.3 & 1.0 & 1.6 & 1.0 & 1.6 & 1.0 & 1.4 \\
\hline 6. Textiles & 321 & 9.8 & 9.7 & 10.1 & 10.1 & 15.7 & 16.4 & 16.5 & 17.3 & 16.4 & 17.0 \\
\hline 7. Clothing & 322 & 48.6 & 48.5 & 51.1 & 51.2 & 119.6 & 120.7 & 127.1 & 128.4 & 124.1 & 124.9 \\
\hline 8. Leather Products & 323 & 56.7 & 56.6 & 62.3 & 62.4 & 92.1 & 93.3 & 102.1 & 103.3 & 101.0 & 101.8 \\
\hline 9. Footwear & 324 & 35.9 & 35.9 & 38.2 & 38.2 & 63.2 & 63.7 & 67.8 & 68.3 & 67.2 & 67.6 \\
\hline 10. Wood Products & 331 & 1.0 & 1.0 & 0.9 & 1.0 & 1.9 & 2.5 & 1.8 & 2.5 & 2.5 & 3.0 \\
\hline 11. Furniture Fixtures & 332 & -0.9 & -1.0 & -1.2 & -1.2 & -1.4 & -0.4 & -1.7 & -0.6 & -1.7 & -0.9 \\
\hline 12. Paper Products & 341 & 0.8 & 0.7 & 0.5 & 0.6 & -11.6 & -10.7 & -12.3 & -11.2 & -11.6 & -10.8 \\
\hline 13. Printing \& Publishing & 342 & -1.6 & -1.7 & -2.0 & -1.9 & -2.2 & -1.3 & -2.6 & -1.6 & -2.6 & -1.9 \\
\hline 14. Fertiliser & $35 \mathrm{~A}$ & 0.1 & 0.0 & 0.2 & 0.3 & -11.7 & -11.1 & -12.0 & -11.2 & -12.2 & -11.7 \\
\hline 15. Other Chemicals & $35 \mathrm{~B}$ & -2.7 & -2.8 & -3.2 & -3.2 & -1.6 & -1.0 & -2.0 & -1.2 & -1.1 & -0.6 \\
\hline
\end{tabular}




\begin{tabular}{|c|c|c|c|c|c|c|c|c|c|c|c|}
\hline 16. Petroleum Products & $35 \mathrm{C}$ & 4.6 & 0.0 & 22.8 & 0.0 & 4.5 & 6.2 & 5.7 & 7.6 & 7.4 & 8.7 \\
\hline 17. Rubber Products & 355 & 11.8 & 11.7 & 12.8 & 12.9 & 15.2 & 16.2 & 16.7 & 17.9 & 17.8 & 18.6 \\
\hline 18. Non-metallic Min. Prod. & $36 \mathrm{~A}$ & 29.8 & 29.7 & 33.4 & 33.4 & 53.0 & 53.9 & 59.8 & 60.9 & 59.9 & 60.7 \\
\hline 19. Glass Products & 362 & 32.2 & 32.1 & 36.1 & 36.1 & 58.1 & 59.0 & 65.8 & 66.8 & 66.3 & 67.0 \\
\hline 20. Iron \& Steel & 371 & -36.6 & 0.0 & -49.0 & 0.0 & -9.0 & -8.4 & -11.8 & -11.1 & -10.1 & -9.7 \\
\hline 21. Non-ferrous Metal & 372 & -2.2 & -2.3 & -2.1 & -2.1 & -28.2 & -27.3 & -33.6 & -32.6 & -30.3 & -29.7 \\
\hline 22. Metal Products & 381 & -4.6 & -4.7 & -6.3 & -6.2 & -5.2 & -4.3 & -7.1 & -6.0 & -6.0 & -5.3 \\
\hline 23. Non-electrical Machinery & 382 & -22.7 & -22.8 & -28.1 & -28.0 & -26.1 & -25.3 & -31.4 & -30.4 & -28.8 & -28.2 \\
\hline 24. Electrical Machinery & 383 & -5.3 & -5.4 & -6.4 & -6.3 & -5.4 & -4.7 & -6.5 & -5.7 & -4.7 & -4.2 \\
\hline 25. Transport Equipments & 384 & 4.4 & -4.4 & -4.7 & 4.7 & -4.6 & -4.2 & -5.1 & -4.5 & -3.9 & -3.5 \\
\hline 26. Misc. Manufacturing & $38 \mathrm{~A}$ & 1.7 & 1.6 & 1.5 & 1.5 & 3.1 & 3.8 & 3.1 & 3.9 & 4.3 & 4.8 \\
\hline 27. Mining \& Quarrying & 2 & 7.5 & 0.0 & 15.1 & 0.0 & -28.3 & -26.9 & -26.8 & -25.2 & -25.2 & -24.1 \\
\hline 28. Electricity, Gas \& Water & 4 & 4.8 & 0.0 & 5.0 & 0.0 & 1.1 & 3.2 & 1.0 & 3.4 & 1.8 & 3.4 \\
\hline 29. Construction & 5 & 0.1 & 0.0 & -0.1 & 0.0 & 0.6 & 1.6 & 0.4 & 1.5 & 1.2 & 2.0 \\
\hline 30. Wholesale \& Retail Trade & 6 & 1.5 & 1.4 & 1.1 & 1.3 & 1.4 & 3.5 & 1.1 & 3.5 & 1.6 & 3.2 \\
\hline 31. Rail Transport & $7 \mathrm{~A}$ & 0.3 & 0.0 & 0.2 & 0.0 & 0.4 & 1.7 & 0.3 & 1.9 & 1.1 & 2.1 \\
\hline \multicolumn{12}{|l|}{ 32. Other Transport, Storage } \\
\hline$\&$ Com & $7 \mathrm{~B}$ & -3.6 & -3.7 & -4.3 & -4.2 & -3.4 & -2.1 & -4.1 & -2.6 & -3.1 & -2.1 \\
\hline \multirow{2}{*}{$\begin{array}{l}\text { 33. Finance In } \\
\text { 34. Comm., S } \\
\text { Pers. Serv }\end{array}$} & 8 & -0.6 & -0.8 & -1.0 & -0.8 & -1.6 & -0.1 & -1.9 & -0.2 & -1.6 & -0.5 \\
\hline & 9 & -0.3 & -0.4 & -0.5 & -0.4 & -0.3 & 0.7 & -0.5 & 0.7 & -0.2 & 0.5 \\
\hline
\end{tabular}


TABLE 10

Changes in Exports and Imports - Stage II - (Per cent)

\begin{tabular}{|c|c|c|c|c|c|c|c|c|c|c|c|}
\hline \multirow{3}{*}{ SN Sectors } & \multirow{3}{*}{ ISIC } & \multicolumn{4}{|c|}{$\begin{array}{c}\text { Trade Reforms } \\
\text { Administered Version }\end{array}$} & \multicolumn{4}{|c|}{$\begin{array}{c}\text { Trade and Domestic Policy Reforms } \\
\text { Market Version }\end{array}$} & \multirow{2}{*}{\multicolumn{2}{|c|}{$\begin{array}{c}\text { Trade and Domestic } \\
\text { Policy Reforms and } \\
\text { Indirect Tax } \\
\text { Rationalisation } \\
\text { Overall }\end{array}$}} \\
\hline & & \multicolumn{2}{|c|}{ Import Reforms } & \multicolumn{2}{|c|}{$\begin{array}{c}\text { Import \& Export } \\
\text { Reforms }\end{array}$} & \multicolumn{2}{|c|}{ Import Reforms } & \multicolumn{2}{|c|}{$\begin{array}{c}\text { Import \& Export } \\
\text { Reforms }\end{array}$} & & \\
\hline & & Exports & Imports & Exports & Imports & Exports & Imports & Exports & Imports & Exports & Imports \\
\hline 1. Paddy & $1 \mathrm{~A}$ & 12.9 & -0.9 & 51.1 & 1.0 & 12.4 & 5.2 & 50.8 & 7.1 & 50.3 & 7.6 \\
\hline 2. Wheat & $1 \mathrm{~B}$ & 12.9 & -0.8 & 51.1 & -1.0 & 12.5 & 5.2 & 50.9 & 7.1 & 50.2 & 7.7 \\
\hline 3. Other Cereals & $1 \mathrm{C}$ & 12.6 & 5.7 & 50.9 & 7.8 & 12.4 & 6.0 & 50.8 & 7.9 & 50.3 & 8.3 \\
\hline 4. Rest of Agriculture & $1 \mathrm{D}$ & 25.3 & -0.1 & 51.7 & 5.1 & 24.8 & 0.9 & 51.4 & 5.8 & 50.6 & 6.9 \\
\hline 5. Food, Bev. \& Tobacco & 310 & 64.7 & 32.1 & 71.0 & 34.1 & 65.5 & 32.2 & 72.5 & 34.0 & 71.0 & 34.4 \\
\hline 6. Textiles & 321 & 83.6 & 9.0 & 88.2 & 15.0 & 97.0 & 8.1 & 103.1 & 13.6 & 102.0 & 14.2 \\
\hline 7. Clothing & 322 & 85.5 & -24.8 & 90.3 & -20.7 & 210.1 & -51.2 & 223.8 & 49.3 & 218.4 & -47.1 \\
\hline 8. Leather Products & 323 & 67.4 & 22.0 & 74.7 & 24.7 & 108.4 & 20.1 & 120.7 & 22.2 & 119.2 & 22.7 \\
\hline 9. Foot wear & 324 & 94.5 & 25.3 & 100.6 & 26.8 & 165.9 & 20.9 & 177.9 & 21.8 & 176.0 & 22.2 \\
\hline 10. Wood Products & 331 & 37.8 & -12.2 & 70.1 & -4.7 & 37.6 & -11.2 & 70.3 & -4.1 & 69.6 & -2.8 \\
\hline 11. Furniture Fixtures & 332 & 61.2 & 39.71 & 68.0 & 43.0 & 59.8 & 40.1 & 66.9 & 43.2 & 66.1 & 43.6 \\
\hline 12. Paper Products & 341 & 61.1 & 0.5 & 68.0 & 0.4 & 62.0 & 53.2 & 69.6 & 55.5 & 69.5 & 55.6 \\
\hline 13. Printing \& Publishing & 342 & 61.3 & 21.5 & 68.2 & 24.8 & 60.9 & 21.5 & 68.3 & 24.5 & 68.6 & 24.5 \\
\hline 14. Fertiliser & $35 \mathrm{~A}$ & 10.0 & 0.0 & 68.6 & 0.3 & 10.6 & 52.7 & 69.5 & 54.4 & 69.3 & 54.7 \\
\hline 15. Other Chemicals & $35 \mathrm{~B}$ & 41.1 & 38.8 & 51.1 & 45.4 & 44.6 & 37.0 & 55.4 & 43.0 & 56.1 & 42.6 \\
\hline
\end{tabular}




\begin{tabular}{|c|c|c|c|c|c|c|c|c|c|c|c|}
\hline 16. Petroleum Products & $35 \mathrm{C}$ & 10.0 & 0.2 & 68.6 & 0.3 & 11.7 & 47.3 & 70.8 & -38.0 & 71.5 & -44.4 \\
\hline 17. Rubber Products & 355 & 62.6 & 35.3 & 70.2 & 42.5 & 73.9 & 33.4 & 83.2 & 39.8 & 84.5 & 39.3 \\
\hline 18. Non-metallic Min. Prod. & $36 \mathrm{~A}$ & 59.0 & 18.6 & 66.5 & 23.2 & 206.5 & -2.3 & 120.3 & -0.8 & 119.6 & 0.5 \\
\hline 19. Glass Products & 362 & 61.9 & 1.7 & 69.9 & 6.0 & 111.5 & -17.5 & 126.6 & -16.3 & 127.1 & -16.2 \\
\hline 20. Iron \& Steel & 371 & 79.9 & -4.0 & 84.2 & -5.1 & 76.8 & 23.1 & 80.4 & 30.0 & 82.5 & 29.6 \\
\hline 21. Non-ferrous Metal & 372 & 40.0 & -3.3 & 79.6 & -4.1 & 40.1 & 42.8 & 80.2 & 52.1 & 81.7 & 50.2 \\
\hline 22. Metal Products & 381 & 39.7 & 24.6 & 49.5 & 31.8 & 39.2 & 25.2 & 48.9 & 32.3 & 49.7 & 31.9 \\
\hline 23. Non-electrical Machinery & 382 & 55.6 & 35.1 & 63.5 & 42.5 & 57.2 & 35.8 & 65.7 & 42.9 & 67.1 & 41.9 \\
\hline 24. Electrical Machinery & 383 & 78.3 & 48.0 & 83.3 & 52.7 & 82.1 & 48.2 & 87.6 & 52.6 & 90.2 & 52.0 \\
\hline 26. Misc. Manufacturing & $38 \mathrm{~A}$ & 81.8 & 26.8 & 86.5 & 28.7 & 88.1 & 26.7 & 93.7 & 28.5 & 96.2 & 28.3 \\
\hline 27. Mining\& Quarrying & 2 & 12.9 & 2.7 & 71.1 & 3.6 & 16.7 & 53.3 & 75.3 & 56.0 & 75.1 & 56.7 \\
\hline 28. Electricity, Gas \& Water & 4 & 4.0 & 2.2 & 12.1 & 2.3 & 14.6 & 42.4 & 12.9 & 455.4 & 12.4 & 46.3 \\
\hline 29. Construction & 5 & 28.8 & 42.2 & 25.2 & 45.4 & 29.6 & 41.7 & 26.3 & 44.6 & 26.6 & 44.5 \\
\hline 30. Wholesale \& Retail Trade & 6 & 13.9 & 52.7 & 12.1 & 54.7 & 13.9 & 53.1 & 12.2 & 55.0 & 11.8 & 55.5 \\
\hline 31. Rail Transport & $7 \mathrm{~A}$ & & & & & & & & & & \\
\hline \multicolumn{12}{|l|}{ 32. Other Transpor } \\
\hline$\&$ Com & $7 \mathrm{~B}$ & 14.0 & 48.5 & 12.2 & 50.8 & 15.2 & 48.5 & 13.6 & 50.6 & 13.8 & 50.5 \\
\hline Pers. Serv. & 9 & 14.0 & -25.1 & 12.2 & -21.8 & 13.8 & -24.8 & 12.1 & -21.7 & 11.8 & -21.2 \\
\hline
\end{tabular}


shift the terms of trade in favour of Indian agriculture. Finally, not only are there efficiency enhancing intersectoral shifts in resource allocation, but there are notable scale economy increases across the Indian manufacturing sectors. ${ }^{9}$

Our results reflect of course the particular assumptions that have been incorporated into our CGE modeling framework as well as the choice of the key parameters used. While it would be desirable to compare the results of our analysis with what has actually happened since 1991-92, this is very difficult to do ex-post because of the influence of various macroeconomic factors as well as other changes that our model does not capture. Moreover, we have not made any allowance for absence of an exit policy that may constrain the movement of labour across sectors of production. However, in our scenarios, by assuming that factor demands increased in expanding sectors enough to employ any factors released by contracting sectors, the pull of new employment may be presumed eventually to overcome any frictions that impede exit. We have also not incorporated certain international constraints on India's exports such as the MultiFibre Agreement (MFA) and NTBs against India's exports by various importing countries. Nevertheless, in our view, the positive results go a long way in establishing the credibility of the Indian policy-reforms process. Granting this, we hope that our research will provide the basis for further analysis of the economic consequences of India's reforms and serve to support the future continuance of these reforms in enhancing the nation's economic efficiency and welfare. ${ }^{10}$

\section{REFERENCES}

Bandara, J. S. (1991), 'Computable General Equilibrium Models for Development Policy Analysis in LDCs,' Journal of Economic Surveys, 5, 3-67.

Bhagwati, J. and T.N. Srinivasan (1993), 'India's Economic Reforms', paper prepared for the Ministry of Finance, Government of India.

Brown, D. K., A. V. Deardorff and R. M. Stern (1993), 'Protection and Real Wages: Old and New Trade Theories and Their Empirical Counterparts', Discussion Paper No. 331 (Research Forum in International Economics, University of Michigan, May).

Brown, D. K., A. V. Deardorff and R. M. Stern (1995), 'Expanding NAFTA: Economic Effects of Accession of Chile and Other Major South American Nations', North American Journal of Economics and Finance, 6, 149-70.

\footnotetext{
${ }^{9}$ While it would be interesting to compare the results of our study with other CGE studies of India's economic reforms, we are not aware of any such studies dealing with the post-1991 period. Bandara (1991) reports six studies of the Indian economy using a CGE approach conducted during the 1980s. However, most of these earlier studies focused on issues relating to growth and income distribution rather than liberalisation of trade and domestic policy.

${ }^{10}$ As mentioned earlier, our model focuses only on India and takes world prices as given. In future work we plan to integrate our India CGE model into the multi-country BDS-CGE Michigan model of world production and trade. This would enable us to analyse the global impact of India's policy reforms on its economy as well as actual and potential future changes in multilateral and regional trade policies and arrangements.
} 
Brown, D. K., A. V. Deardorff and R. M. Stern (1996), 'Computational Analysis of the Economic Effects of an East Asian Preferential Trading Bloc', Journal of the Japanese and International Economies 10, 37-70.

Brown, D. K., A. V. Deardorff, S. Djankov, and R. M. Stern (1996), 'An Economic Assessment of the Integration of Czechoslovakia, Hungary, and Poland into the European Union', in S. Black (ed.), Europe's Economy Looks East (New York: Cambridge University Press).

Chadha, R., S. Pohit, and P.L. Bina (1995), 'Capital-Labor Substitution in Indian Industries', presented in The Thirty-First Annual Conference of the Indian Econometric Society (National Institute of Bank Management, 12-14 May, Pune).

Chadha, R., S. Pohit, A. V. Deardorff and R. M. Stern (1996a), 'The India Model of Production, Trade and Employment', Working Paper No. 64 (National Council of Applied Economic Research, New Delhi).

Chadha, R., S. Pohit, A. V. Deardorff and R. M. Stern (1996b), 'Analysis of India's Reforrns: A CGE Modelling Exercise', Working Paper No. 65 (National Council of Applied Economic Research, New Delhi).

Chadha, R., S. Pohit, A. V. Deardorff and R. M. Stern (1997). The Impact of Trade and Domestic Policy Reforms in India: A CGE Modeling Approach (The University of Michigan Press, Ann Arbor, forthcoming).

Deardorff, A. V. and R. M. Stern (1990), Computational Analysis of Global Trading Arrangement (The University of Michigan Press, Ann Arbor).

Francois, J. F. And K. A. Reinert (eds.) (1997), Applied Methods for Trade Policy Analysis: A Handbook (Cambridge University Press, Cambridge and New York).

Government of India (1991), Tax Reforms Committee: Interim Report, Chairman: R. J. Chelliah, Ministry of Finance.

Government of India (1992), Tax Reforms Committee: Final Report Part I, Chairman: R. J. Chelliah, Ministry of Finance.

Government of India (1993), Tax Reforms Committee: Final Report Part II, Chairman: R. J. Chelliah, Ministry of Finance.

Gulati, A. and R. Chadha (1995), 'India Poised for Take-off? Reforms in Trade, Industry and Agriculture: Stock-Taking and Future Challenges', R. Kapila and U. Kapila (eds.), in Understanding India's Economic Reforms: The Past, The Present, and The Future (Delhi Academic Foundation).

Harrison, W. J. and K. R. Pearson (1996) 'Computing Solutions for Large General Equilibrium Models Using GEMPACK', Computational Economics, 9, 83-87.

Joshi, V. and I.M.D. Little (1994), India: Macroeconomics and Political Economy 1964-1991 (World Bank, Washington DC).

Joshi, V. and I.M.D. Little (1996), India's Economic Reforms: 1991-2001 (Clarendon Press, Oxford).

Martin, W. and L. A. Winters (eds.) (1996), The Uruguay Round and Developing Countries (Cambridge University Press, New York).

World Bank (1989), 'India: An Industrialising Economy in Transition', A World Bank Country Study. 